Original Paper

doi $10.15826 /$ recon.2020.6.4.024

JEL H23, Q52

\title{
Analysis of the transport tax system in the People's Republic of China
}

\author{
Ma Jun $\bowtie$, I.A. Mayburov \\ Ural Federal University named after the first President of Russia B.N. Yeltsin, Ekaterinburg, Russia; ma_dreama@hotmail.com
}

\section{ABSTRACT}

Relevance. The rapid development of the transportation industry has led to economic development and at the same time has had a negative impact on the environment, especially in developing countries. Taxation can play an important role in regulating the number of vehicles in the country. Unfortunately, in China, taxation does not fully play its regulatory role. Research objective. This article focuses on the problems of environmental pollution and traffic congestions in large cities and ways of tackling them with the help of transportation tax reforms. Data and methods. This article adopts the method of comparative analysis and selects countries such as Japan, Singapore, and France to analyze their experience with that of China in the sphere of transportation taxation. The analysis concentrates around the three main aspects of taxation: vehicle purchase, vehicle use and discarding of old vehicles. The research data are taken from the Chinese government's official website and the results of previous research. Results. There is still a lot of room for improvement in China's transportation taxation system. Feasible suggestions should be drawn up to improve the existing taxation policies. Conclusions. In order to improve China’s transport taxation policy, the study makes a number of proposals regarding the tax on the purchase of vehicles, tax on the use of vehicles and ships, tax on the consumption of refined oil, etc. These proposals can help China embark on a sustainable development path to achieve the goal of coordinated economic, environmental and energy development.
\end{abstract}

\section{KEYWORDS}

vehicle ownership tax, fuel tax, central entry tax, gas tax, traffic congestion, environmental protection, energy saving, economic development, sustainable development

\section{ACKNOWLEDGEMENTS}

This research was funded by the China Scholarship Council.

\section{FOR CITATION}

Jun, Ma, Mayburov, I.A. (2020) Analysis of the transport tax system in the People's Republic of China. R-economy, 6(4), 271-279. doi: $10.15826 /$ recon.2020.6.4.024

\section{Анализ системы транспортного налогообложения в Китайской народной республике}

\author{
Ма Цзюнь $\bowtie$, И.А. Майбуров
}

Уральский федеральный университет им. первого Президента России Б.Н. Ельцина, Екатеринбург, Россия; ma_dreama@hotmail.com

\begin{abstract}
АННОТАЦИЯ
Актуальность. Быстрое развитие транспортной отрасли привело к экономическому развитию и в то же время негативно сказалось на окружающей среде. Это явление особенно ярко наблюдается в развивающихся странах. И налогообложение здесь может сыграть важную роль в регулировании количества транспортных средств. К сожалению, на текущий момент оно такую роль не играет. Цель исследования. Эта статья нацелена на анализ использования инструментов налогообложения для решения проблем загрязнения окружающей среды и транспортных заторов, вызванных движением транспорта, а также на разработку практических эффектов налогообложения. Данные и методы. В этой статье используется метод сравнительного анализа. Для сравнения выбираются страны, которые достигли значительных результатов в сфере транспортного налогообложения, такие как Япония, Сингапур и Франция. Текущая ситуация с транспортным налогообложением в Китае проанализирована в трех аспектах: покупка, использование и переработка автомобилей. Данные для исследования взяты с официального сайта правительства и результатов предыдущих исследований. Результаты. Мы показали, что в системе транспортного налогообложения Китая есть еще много возможностей для улучшения. Подготовлены реальные предложения по улучшению существующей политики в сфере транспортного налогообложения. Выводы. Чтобы улучшить политику транспортного налогообложения Китая, исследование вносит ряд предложений касательно налога на покупку транспортных средств, налога на использование транспортных средств и судов, налога на потребление рафинированной нефти и т.д. Эти предложения могут помочь Китаю встать на путь устойчивого развития для достижения цели скоординированного развития экономики, окружающей среды и энергетики.
\end{abstract}

\section{КЛЮЧЕВЫЕ СЛОВА}

налог на владение транспортным средством, налог на топливо, центральный въездной налог, налог на газ, дорожные заторы, охрана окружающей среды, энергосбережение, экономическое развитие, устойчивое развитие

\section{БЛАГОДАРНОСТИ}

Это исследование финансировалось Китайским стипендиальным советом.

\section{ДЛЯ ЦИТИРОВАНИЯ}

Jun, Ma, Mayburov, I.A. (2020) Analysis of the transport tax system in the People's Republic of China. R-economy, 6(4), 271-279. doi: 10.15826/recon.2020.6.4.024 


\section{Introduction}

At present, the problem of environmental pollution in China's transportation industry has become increasingly prominent. Traffic pollution in super large cities and densely populated areas in the east contributes $10 \%$ to $50 \%$ of $\mathrm{PM}_{2.5}$ concentration. According to the 'Annual Report on China's Motor Vehicle Environmental Management' issued by the Ministry of Ecology and Environment, as of 2019, China has become the world's largest country in motor vehicle production and sales for ten consecutive years ${ }^{1}$. According to the data released by the National Bureau of Statistics, the average annual growth rate of China's GDP from 1990 to 1995 exceeded 10\%, but the loss caused by environmental pollution in the same period reached $8 \%$. It means that the economic growth is offset by environmental pollution and resource consumption (Verhoef, 1994). The experience of developed countries shows that economic policies, especially taxation policies, are an important means to control environmental pollution in the transportation industry. Taxes and fees levied on automobile consumption can help control the number of cars (Clarke \& Prentice, 2009). At the same time, the tax policy also has a guiding effect on the purchase of new energy vehicles ( $\mathrm{Wu} \& \mathrm{Hu}, 2010$ ).

This article aims to investigate the problems of energy waste, environmental pollution and traffic congestion caused by transportation and to formulate practical taxation plans. In order to achieve this goal, two main tasks are set:

1) to analyze taxation policies of the transportation industry in Japan, Singapore, and France to find out the shortcomings of China's automobile taxation measures;

2) to formulate recommendations that could help improve China's transportation tax system.

In this article we describe the theoretical framework of the research problem and provide an overview of Chinese and international research on transportation taxation. Moreover, we are going to look at three aspects of transportation taxation: car purchase, car use and discarding of all vehicles. We will compare the experience of Singapore, France and Japan with that of China. Then we will analyze the existing problems and

${ }^{1}$ Ministry of Ecology and Environment of the People's Republic of China. The Ministry of Ecology and Environment released the 'Annual Report on Environmental Management of China Mobile Sources (2019)'. 2019-09-04. Retrieved from: https://www.primorsky.ru/news/164469/ (Accessed: 30.03.2020) put forward practical and feasible tax policy recommendations by focusing on the three aspects of automobile purchase, use and recycling, which are conducive to the sustainable development of China's transportation industry. Finally, based on the results of analysis and research, we are going to summarize the problems of the traffic tax system and feasibility of the traffic tax system improvements.

Our research results can be useful for policy-makers in the sphere of transport taxation because this taxation can effectively eliminate the difference between private costs and social costs (Wardrop, 1952). The reform of the transportation tax is an effective fiscal method for exploring sustainable development in China. Sustainable development requires the authorities to pay attention to economic development while ensuring the harmony of the environment (Dasgupta, 2007). The reform has introduced regulations for the whole process of buying cars, using cars, and recycling cars (Baumol, 1972). Transport taxation helps to turn negative external losses into internal costs, eliminate the negative impact of external factors on society and the economy, and ensure sustainable development (Mayburov \& Leontyeva, 2019).

\section{Theoretical framework and methodology}

Tietenberg (1990) conducted an empirical study on the minimization of pollution costs and compared the adjustment of environmental taxes with other policy measures. The results prove that environmental taxes can achieve ideal pollution control and environmental protection incentives. Gilbert (2003) made a more comprehensive and systematic discussion of green taxation problems, including the meaning, classification, working principles, effect, reference, etc. of the green tax policy. Koskela et al. (2001) believe that in order to effectively use energy, some economic policies need to be adopted, such as levying emission taxes on greenhouse gases. Goulder (1995) found that by reviewing the vehicle tax literature, each additional vehicle tax would reduce $\mathrm{CO} 2$ emissions by $0.19 \%$, and congestion charges would reduce vehicles by $9-12 \%$ and improve environmental quality.

Leontyeva \& Mayburov (2016) show that the evolution of studies on transport taxation involved the development of a range of economic measures, from fees for the use of particular road 
network facilities to fees for the use of the whole road network.

Current research focuses on the specifics of national systems of transport taxation and their ability to actively perform fiscal and regulatory functions. Leontyeva (2019) considers various aspects of transport taxation in Russia and Söllner (2018) studies the specifics of the construction of transport taxation in Germany.

China's research on the transportation tax has been conducted for more than ten years, and there have been a lot of achievements in this field. Guo et al. (2014) simulated the economic impact of China's fuel consumption tax by building a model of 'energy-economy-environment'. The simulation results show that the fuel consumption tax will have a negative impact on China's economic growth, residents' welfare and the development of some industries, but it will effectively promote the reduction of domestic demand for refined oil, which can reduce oil imports and further guarantee energy security. Qu \& Lu (2008) examined the conditions for the fuel consumption tax in China from the perspective of the tax system, and believe that the energy tax policy in China's current tax system has played a role in promoting energy conservation and effective use, but there is still a problem. The Chinese government should benefit from the opportunity of introducing a fuel consumption tax. It is necessary to continuously improve the taxation of energy production and consumption to gradually form an energy taxation system suitable for China's national conditions.

In recent years, China has upheld the development philosophy of innovation, coordination, greenness, openness, and sharing, and has always unswervingly taken sustainable development as a basic national policy to promote high-quality economic development in China ${ }^{2}$. The idea of sustainable development has been widely used in economics and sociology and has acquired some new meanings (Norgaard, 1988; Costanza \& Folke, 1994). The Fifth Plenary Session of the Eighteenth Central Committee put forward the following principle: 'Adhering to green development means adhering to the basic national policy of saving resources and protecting the environment, adhering to sustainable development,

\footnotetext{
${ }^{2} \mathrm{Hu}$ Jintao (2004). Speech at the Central Symposium on Population, Resources and Environment. People's Daily, first edition, April 5. Retrieved from: http://www.people.com.cn/ GB/shizheng/1024/2427943.html
}

forming a new pattern of modernization for the harmonious development of mankind and nature, and making new contributions to global ecological security's.

To sum up, the reform of transportation tax is conducive to the improvement of China's taxation system. Although many scholars have put forward specific suggestions on the construction of China's transportation tax system, these studies have certain limitations due to various reasons. While they have a robust theoretical framework, they often lack empirical data. This article seeks to address this research gap by using the Pigovian Tax Theory (Pigou, 1920) and the sustainable development theory (Meadows et al, 1972).

\section{Results}

\section{Vehicle purchase tax}

The purchase tax mainly refers to the types of taxes incurred when purchasing vehicles, mainly including the vehicle purchase tax and consumption tax. For example, Japan has set two types of taxes: vehicle purchase tax and consumption tax. The vehicle purchase tax is levied ad valorem and set at different tax rates. The tax rate for commercial vehicles and light vehicles is $2 \%$ of the retail price, and the tax rate for private cars is $3 \%$.

In order to encourage the purchase of new energy vehicles, Sweden has greatly reduced the taxes and fees for vehicles using clean fuels and provides tax rebates or full tax exemptions for the purchase and use of clean fuel vehicles (Dannenberg et al., 2008).

Chinese consumers need to pay the consumption tax and vehicle purchase tax when purchasing vehicles. The objects of taxation are units and individuals who purchase taxable vehicles in China, and the tax rate is $10 \%$ of the sales price. The taxation scope of vehicle consumption tax mainly includes passenger cars, medium and light commercial buses, etc. Depending on vehicle emissions, tax rates range from $1 \%$ to $40 \%$ (Table 1).

China's vehicle purchase tax is levied uniformly, regardless of vehicle emissions or energy consumption, and its preferential policies are only applicable to new energy vehicles (NEVs), that is, vehicles that are partially or fully powered by electricity. For low-emission, low-energy non-new

${ }^{3}$ Xi Jinping (2015). Persist in green development and build a beautiful China. Xinhua News Agency, November 1 . Retrieved from: http://www.ccdi.gov.cn/special/wzqh/pl wzqh/201511/t20151102 64300.html 
Table 1

Car consumption tax rate table

\begin{tabular}{|c|c|c|c|}
\hline \multirow{2}{*}{\multicolumn{2}{|c|}{ Tax object }} & \multicolumn{2}{|l|}{ Tax rate } \\
\hline & & \multirow{2}{*}{$\begin{array}{c}\text { Production (import) } \\
1 \%\end{array}$} & \multirow[t]{2}{*}{ Retail } \\
\hline \multirow{7}{*}{ 1. Passenger car } & (1) Cylinder volume below 1.0 L (including 1.0 L) & & \\
\hline & (2) Cylinder capacity greater than $1.0 \mathrm{~L}$ is less than or equal to $1.5 \mathrm{~L}$ & $3 \%$ & \\
\hline & (3) Cylinder capacity greater than $1.5 \mathrm{~L}$ less than or equal to $2.0 \mathrm{~L}$ & $5 \%$ & \\
\hline & (4) Cylinder capacity greater than $2.0 \mathrm{~L}$ less than or equal to $2.5 \mathrm{~L}$ & $9 \%$ & \\
\hline & (5) Cylinder capacity greater than $2.5 \mathrm{~L}$ less than or equal to $3.0 \mathrm{~L}$ & $12 \%$ & \\
\hline & (6) Cylinder capacity greater than $3.0 \mathrm{~L}$ less than or equal to $4.0 \mathrm{~L}$ & $25 \%$ & \\
\hline & (7) Cylinder volume above 4.0L & $40 \%$ & \\
\hline \multicolumn{2}{|c|}{ 2. Medium and light commercial bus } & $5 \%$ & \\
\hline \multicolumn{2}{|c|}{ 3. Super luxury car } & $\begin{array}{l}\text { Based on the tax } \\
\text { object } 1 \text { or } 2\end{array}$ & $10 \%$ \\
\hline
\end{tabular}

Source: compiled by the authors on the basis of 'Notice on the Collection of the Motor Vehicle Consumption Tax'. (Accessed: 23.03.2020)

energy vehicles, there is a lack of relevant preferential policies. Although there are currently subsidies and tax incentives for new energy vehicles, these two policies will be implemented until 2020, and the cost of new energy vehicles is relatively high $^{4}$. It can be seen that China's current tax and preferential policies are not enough to stimulate consumers to buy more environmentally friendly vehicles. In addition, the current automobile consumption tax in China is directly charged on car manufacturers and then passed on to the price of the car. Therefore, most consumers do not care about the consumption tax when buying vehicles, but only pay attention to the price.

\section{Taxation of car ownership and car use}

Vehicle taxation mainly includes taxes on car ownership, taxes on the consumption of petroleum products, taxes on travel to specific areas and taxes on exhaust emissions. The purpose of taxation in the field of car use is to reduce exhaust emissions and protect the environment (Small et al., 2007).

Japan imposes three taxes on car ownership, including the car tax, light car tax and car weight tax. According to the automobile tax regulations, private cars and commercial vehicles are divided into 9 levels depended on the amount of exhaust gas and taxed separately. The annual tax is $29,500-88,000$ yen; on this basis, the use of vehicles is further differentiated, and different tax rates are stipulated; the rate of the vehicle weight tax depends not only on the weight of the vehicle

\footnotetext{
${ }^{4}$ Zhao Ying (2019). New energy vehicle consumption still receives policy support. Retrieved from: http://paper.people.com.cn/zgnyb/html/2019-07/15/content 1936452.htm
}

but also on its use. Japan also uses high fuel consumption costs to reduce the frequency of vehicle use and encourage consumers to use less fuel, buy more economical small vehicles and even reduce the purchase of vehicles.

The most common form is restricted area charging, that is, users who enter a specific area are charged a certain tax. The purpose is to reduce regional pollution emissions and unnecessary energy consumption (Holden, 1989; Levinson, 2010). Singapore is the first country to implement congestion charging. In 1975, Singapore began to implement the Area Pass System (ALS) in the city's central business district of 725 hectares. After more than 20 years of operation, there is evidence that the regional pass scheme is an effective means to control the traffic during peak hours: the number of motor vehicles entering the control zone in the early peak period has dropped from 74,000 per day to 41,500 per day; the driving speed has increased by $20 \%$; the proportion of the population using public transportation has increased from 33\% to 69\%; and fiscal revenue has increased. These policies alleviated traffic congestions, increased revenue and helped manage urban pollution ${ }^{5}$.

In order to strengthen the control of automobile exhaust emissions, the European Union mainly levies taxes on automobile carbon dioxide emissions, and sets different tax rates according to emission levels, fuel types and regional categories. Cars that exceed the specific level of carbon dioxide emissions are subject to higher

5 Tan Bonny (2016). Electronic toll system. Government Web sites of Singapore. Retrieved from: https://eresources.nlb. gov.sg/infopedia/articles/SIP 832 2009-01-05.html 
taxes (IPCC, 2001). France has established a reward and penalty tax system based on carbon dioxide emissions. The tax targets are passenger cars and light commercial vehicles registered in France for the first time. Depending on the amount of carbon dioxide emissions, consumers are required to pay certain punitive taxes (Figure 1) or be rewarded when registering (Table 2). The purpose of tax rewards and punishments is to respond to global warming by reducing greenhouse gas emissions. Through financial leverage, incentives encourage consumers to switch to low-emission vehicles.

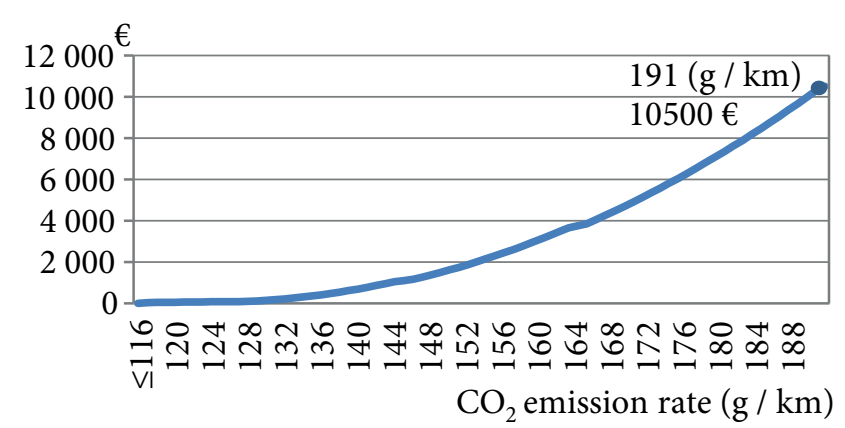

Figure 1. French Ecological Penalty Standards in 2019

Source: Compiled by the authors based on 'Ecological Penalty: Environmental Tax' (Accessed: 12.03.2020)

\section{French Ecological Reward Standards}

\begin{tabular}{|l|l|l|l|}
\hline $\begin{array}{c}\text { CO2 emission } \\
\text { rate }(\mathbf{g} / \mathbf{k m})\end{array}$ & \multicolumn{1}{|c|}{ Vehicle type } & $\begin{array}{c}\text { Bonus amount on } \\
\text { January 1, 2019 }\end{array}$ & \multicolumn{1}{c|}{ Remarks } \\
\hline 0 to $20 \mathrm{~g}$ & Specialized car, van or self-propelled vehicle & $\begin{array}{l}6000 € \\
\text { (within the limit of 27\% } \\
\text { of the acquisition cost) }\end{array}$ & $\begin{array}{l}\text { For 100\% electric vehicles } \\
\text { equipped, if necessary, with a } \\
\text { range extender }\end{array}$ \\
\hline $\begin{array}{l}\text { Without thresh- } \\
\text { old }\end{array}$ & $\begin{array}{l}\text { 2 or 3-wheel motor vehicles and electric motor } \\
\text { quadricycles whose engine has a maximum } \\
\text { net power greater than or equal to 3 } \mathrm{kWh} \text { and } \\
\text { which do not use lead-acid batteries }\end{array}$ & $900 €$ & \\
\hline
\end{tabular}

Source: Compiled by the authors based on 'Ecological Bonus: New Methods' (Accessed: 12.03.2020)

Table 3

Tax rate table for the vehicle and vessel use tax

\begin{tabular}{|c|c|c|c|c|}
\hline & Tax object & Tax unit & $\begin{array}{c}\text { Annual tax } \\
\text { amount }\end{array}$ & Remarks \\
\hline \multirow{7}{*}{$\begin{array}{l}\text { 1. Passenger } \\
\text { car }\end{array}$} & (1) Cylinder volume below 1.0 L (including 1.0 L) & \multirow{7}{*}{ Vehicle } & $60-360$ & \multirow{7}{*}{$\begin{array}{l}\text { The number of pas- } \\
\text { sengers is less than } \\
\text { or equal to } 9\end{array}$} \\
\hline & (2) Cylinder capacity greater than $1.0 \mathrm{~L}$ less than or equal to $1.6 \mathrm{~L}$ & & $300-540$ & \\
\hline & (3) Cylinder capacity greater than $1.6 \mathrm{~L}$ less than or equal to $2.0 \mathrm{~L}$ & & $360-600$ & \\
\hline & (4) Cylinder capacity greater than $2.0 \mathrm{~L}$ less than or equal to $2.5 \mathrm{~L}$ & & $600-1200$ & \\
\hline & (5) Cylinder capacity greater than $2.5 \mathrm{~L}$ less than or equal to $3.0 \mathrm{~L}$ & & $1200-2400$ & \\
\hline & (6) Cylinder capacity greater than $3.0 \mathrm{~L}$ less than or equal to $4.0 \mathrm{~L}$ & & $2400-3600$ & \\
\hline & (7) Cylinder volume above $4.0 \mathrm{~L}$ & & $3600-5400$ & \\
\hline \multirow[b]{2}{*}{$\begin{array}{l}\text { 2. Commer- } \\
\text { cial vehicle }\end{array}$} & Bus & Vehicle & $480-1440$ & $\begin{array}{l}\text { Number of passen- } \\
\text { gers over } 9 \text { (inclu- } \\
\text { ding tram) }\end{array}$ \\
\hline & Truck & $\begin{array}{c}\text { Curb } \\
\text { weight }(t)\end{array}$ & $16-120$ & $\begin{array}{l}\text { 1. Including tractor } \\
\text { semi-trailers, trail- } \\
\text { ers, cars and trucks, } \\
\text { three-wheeled vehi- } \\
\text { cles and low-speed } \\
\text { trucks, etc. } \\
2 . \text { The trailer tax is } \\
50 \% \text { of the truck cost }\end{array}$ \\
\hline \multirow{2}{*}{$\begin{array}{l}\text { 3.Other } \\
\text { vehicles }\end{array}$} & Special operation vehicle & $\begin{array}{c}\text { Curb } \\
\text { weight }(t)\end{array}$ & $16-120$ & \multirow{2}{*}{$\begin{array}{l}\text { Does not include } \\
\text { tractor }\end{array}$} \\
\hline & Wheel special mechanical vehicle & $\begin{array}{c}\text { Curb } \\
\text { weight (t) }\end{array}$ & $16-120$ & \\
\hline $\begin{array}{l}\text { 4. Motor- } \\
\text { cycle }\end{array}$ & & Vehicle & $36-180$ & \\
\hline
\end{tabular}


In China, the tax items levied by the units or individuals that own vehicles and ships during the retention period are called vehicle and vessel use tax. The tax amount is determined by the people's government of the province (autonomous region, municipality directly under the Central Government) in accordance with the tax amount prescribed by the Tax Law of the People's Republic of China and the regulations of the State Council. The tax rate depends on the type and use of the vehicle and is divided into different categories (Table 3). For new energy vehicles, the 'Notice on Preferential Policies for Energy Saving and Use of New Energy Vehicles, Ships, and Vehicles and Taxes' provides that energy-saving vehicles and ships will be taxed by half, and vehicles and ships using new energy will be exempted.

In terms of vehicle use, no taxes are levied specifically on automobiles in China, instead they are included into the price of refined oil. China's refined oil consumption tax uses a fixed tax rate, which is regularly adjusted by the national tax authority. The current tax rate is 1.52 yuan / liter for gasoline and 1.2 yuan / liter for diesel.

China's refined oil consumption tax calculation method is not economically sound. First, China's refined oil consumption tax accounts for about $20 \%$ of the refined oil price, which is lower than the $60 \%$ foreign tax rate; and the difference between the pollution degree of gasoline and diesel is large but the tax rate gap is small. Second, the scope of taxation is relatively narrow. At present, China only levies taxes on gasoline and diesel. In contrast, in addition to levying taxes on traditional gasoline and diesel, Japan also levies taxes on new fuels such as LNG and LPG, which can reduce exhaust emissions and protect the environment.

Compared with other countries, China has no policies or regulations on urban traffic congestion tax. At present, China mainly solves the problem of urban traffic congestions by adopting motor vehicle restrictions on traffic, restrictions on the number of purchases, parking fees on the main trunk roads in urban areas. Although the above measures did play a certain role in easing traffic congestion when they were first put into use, they still could not solve the fundamental problem. As the economy develops steadily, in order to avoid traffic restrictions, wealthier families will tend to buy more cars, which runs counter to the original intention behind the measure. Over time, the problem of traffic congestion will reappear. There- fore, the problem should be solved by increasing the cost of the use phase of the motor vehicle ${ }^{6}$.

At present, China does not collect taxes on car emissions, nor does it impose carbon taxes. With the continuous growth of motor vehicle ownership, its exhaust emissions have become one of the major contributors to air pollution, and some urban motor vehicle emissions have become the primary source of $\mathrm{PM}_{2.5}$. Taxes related to environmental pollution caused by motor vehicle emissions should be determined as soon as possible (Deng et al., 2015).

\section{Vehicle recycling}

The recycling policy for automobile scrap is aimed at promoting the disposal of used vehicles. Developed countries have adopted both charging and incentive policies to encourage people to eliminate obsolete vehicles: for example, Sweden has a policy of charging and rewarding for scrapping vehicles. The policy stipulates that on all motor vehicles under 3.5 tons (except motorcycles) their owners should pay a car scrap tax of 850 SEK, and this revenue is used for scrapped vehicles. Car owners who bring their cars to designated scrap sites are entitled to tax refunds of 500 SEK. The purpose is to encourage people to discard old and large-emission vehicles and repurchase new vehicles that meet higher emission standards. At the same time, the problem of old vehicle disposal has also been addressed.

According to the 'Notice on Liquidation of Old Cars and Renewal of Central Financial Subsidy Fund' issued by the Ministry of Finance on December 28, 2016, the Central Government has canceled the old car scrap subsidies. The local government can decide whether to implement the subsidy policy for air pollution prevention and control. Local subsidy policies are not effective enough to promote the elimination of old vehicles. The amount of the subsidy standard cannot support the purchase of new cars, resulting in a low level of enthusiasm for the voluntary retirement of old vehicles. While China's policy is only to provide subsidies, other countries also levy additional taxes and fees on old vehicles whose age exceeds specific limits. Both charges and discounts are used in combination to promote the elimination of used vehicles.

${ }^{6}$ The Economist (2016). The great crawl of China. Retrieved from: https://www.economist.com/china/2016/06/16/ the-great-crawl 


\section{Discussion}

Our analysis has shown that there are still many weaknesses in China's transportation tax at this stage, which need to be explored. In order to better coordinate the development of economy, environment and energy, it is recommended to improve the traffic tax policy from the following three aspects.

First, it is recommended to separate the actual price of the car from the tax. The vehicle purchase tax should be collected in several stages. Various preferential tax policies such as tax exemption and tax reduction will be fully implemented for new energy vehicle manufacturers to reduce the cost of such vehicles for consumers.

Fuel consumption and exhaust fumes emissions should be taken into consideration when collecting the vehicle and vessel use tax. The increased tax rate is not only acceptable to consumers, but also conducive to environmental improvement. It is advisable to expand the scope of taxation for the refined oil consumption tax and include new fuels such as liquefied petroleum gas and liquefied natural gas into the taxation base. From the perspective of energy types and environmental impact factors, tax standards should also differentiate between diesels, gasoline; electric and solar vehicles based on differences in vehicle power and energy. It is recommended to introduce a traffic congestion tax in congested areas of key cities for vehicles entering the city center within a limited time.

Finally, a policy of combining rewards and punishments is adopted to stimulate people to dispose of old vehicles and replace them.

\section{Conclusions}

China's transportation industry is an important part of the country's economic development. This study focuses on the following problems faced by the transportation industry: first, its huge energy demand (the transportation industry has become the second largest energy consumption industry) and insufficient utilization efficiency, resulting in a large amount of energy waste; second, environmental pollution, especially the increasing amount of $\mathrm{CO}_{2}$ emissions and serious air pollution. All of the above shows that improvement of China's transport taxation system is a pertinent task.

We used the sustainable development theory and the Pigovian Tax Theory to compare and analyze the tax policies of Japan, Singapore, France, and Sweden. The conclusion was made that most of the problems stem from the single tax rate, unbalanced tax rates, and imperfect tax policies in China. The application of the above-mentioned theories has great advantages in guiding the development of energy-saving and environmentally friendly models and reducing air pollution. Our comparative analysis of various taxation systems shows that the following measures could improve the situation in China: separation of price and taxation; optimization of the tax burden structure; improvement of the scientific plan for setting tax rates to solve the problem of energy waste, traffic congestions, and environmental pollution.

Although the research on China's transportation taxation has achieved certain results, there is still a lot of work to be done.

\section{References}

Baumol, W. J. (1972). On taxation and the control of externalities. The American Economic Review, 62(3), 307-322.

Clarke, H., \& Prentice, D. (2009). A Conceptual Framework for the Reform of Taxes Related to Roads and Transport. Canberra, La Trobe University Publ., 69 p.

Costanza, R., \& Folke, C. (1994). Ecological Economics and Sustainable Development. Paper prepared for the international Experts Meeting for the Operationalization of the Economics of Sustainability. Manila, Philippines, July 28-30.

Dannenberg, A., Mennel, T., \& Moslener, U. (2008). What does Europe pay for clean energy? Review of macroeconomic simulation studies. Energy Policy, 36(4), 1318-1330. doi: 10.1016/j.enpol.2007.12.010

Dasgupta, P. (2007). The idea of sustainable development. Sustainability Science, 2(1), 5-11. doi: 10.1007/s11625-007-0024-y 
De Borger, B., \& Mayeres, I. (2007). Optimal taxation of car ownership, car use and public transport: Insights derived from a discrete choice numerical optimization model. European Economic Review, 51, 1177-1204.

Deng, H., Farah, P.D., \& Wang, A. (2015). China's role and contribution in the global governance of climate change: institutional adjustments for carbon tax introduction, collection and management in China. The Journal of World Energy Law \& Business, 8(6), 581-599.

Guo, Z., Zhang, X., Zheng, Y., \& Rao, R. (2014). Exploring the impacts of a carbon tax on the Chinese economy using a CGE model with a detailed disaggregation of energy sectors. Energy Economics, 45, 455-462. doi: 10.1016/j.eneco.2014.08.016

Goulder, L.H. (1995). Effects of Carbon Taxes in an Economy with Prior Tax Distortions: An Intertemporal General Equilibrium Analysis. Journal of Environmental Economics and Management, 29(3), 271-297. doi: 10.1006/jeem.1995.1047

Holden, D.J. (1989). Wardrop's third principle: urban traffic congestion and traffic policy. Journal of Transport Economics and Policy, 23(3), 239-262.

IPCC (2001). Question 7. In (book): Climate Change 2001: Synthesis Report (pp. 122). Cambridge University Press, UK.

Koskela, E., Sinn, H.W., \& Schöb, R. (2001). Green tax reform and competitiveness. German Economic Review, 2(1), 19-30. doi: 10.1111/1468-0475.00025

Leontyeva, Y.V., Mayburov, I.A. (2016). Theoretical framework for building optimal transport taxation system. Journal of Tax Reform, 2(3), 193-207. doi: 10.15826/jtr.2016.2.3.024

Leontyeva Y., Mayburov I. (2019). Environmental effects of fixed and variable transport-related charges in Russia. IOP Conference Series: Earth and Environmental Science, 344(1), 012017. doi: $10.1088 / 1755-1315 / 344 / 1 / 012017$

Levinson D.M. (2010). Equity effects of road pricing: a review. Transport Reviews, 30(1), 33-57.

Mayburov, I., Leontyeva, Y. (2019). Assessment of the external effects of car use in urban and rural areas of modern Russia. IOP Conference Series: Earth and Environmental Science, 344(1), 012006. doi: $10.1088 / 1755-1315 / 344 / 1 / 012006$

Meadows, D.H., Meadows, D.L., Randers, J., \& Behrens, W.W. (1972). The limits to growth. New York: Univers Books, 203 pp.

Metcalf, G.E. (2003). Environmental levies and distortionary taxation: Pigou, taxation and pollution. Journal of Public Economics, 87(2), 313-322. doi: 10.1016/S0047-2727(01)00116-5

Norgaard, R.B. (1988). Sustainable development: a co-evolutionary view. Futures, 20(6), 606-620.

Pigou, A.C. (1920). The Economics of Welfare. London, Macmillan and Co. Publ., 896 pp.

Qu, S., Lu, C. (2008). Reform and improvement of China's energy tax system. China Population Resources and Environment, (3), 163-168 (In Chinese)

Small, K.A., Verhoef, E.T., \& Lindsey, R. (2007). The economics of urban transportation. Routledge.

Söllner, F. (2018). Road traffic taxation in Germany: the present system, its problems and a proposal for reform. Journal of Tax Reform, 4(1), 57-72. doi: 10.15826/jtr.2018.4.1.045

Tietenberg, T.H. (1990). Economic instruments for environmental regulation. Oxford review of economic policy, 6(1), 17-33. doi: 10.1093/oxrep/6.1.17

Verhoef, E. (1994). External effects and social costs of road transport. Transportation Research Part A: Policy and Practice, 28(4), 273-287.

Wardrop, J.G. (1952). Road paper. some theoretical aspects of road traffic research. Proceedings of the institution of civil engineers, 1(3), 325-362.

Wu, J., Hu, Z. (2010). Discussion on taxation policies to promote the development of energy-saving and environmentally friendly automobile industry. Investigation and Research, 5, 46-47. Retrieved from: http://www.cnki.com.cn/Article/CJFDTotal-ZGSW201005030.htm 


\section{Information about the authors}

Ma Jun - Graduate student, Ural Federal University named after the first President of Russia B.N. Yeltsin, Ekaterinburg, Russia (19 Mira St., Ekaterinburg, 620002, Russia); e-mail: ma_dreama@hotmail.com

Igor A. Mayburov - Doctor of Economic Sciences, Professor, Head of the Department of Finance and Tax Management, Ural Federal University named after the first President of Russia B.N. Yeltsin, Ekaterinburg, Russia (19 Mira St., Ekaterinburg, 620002, Russia); e-mail: mayburov.home@gmail.com.

ARTICLE INFO: received August 27, 2020; accepted November 26, 2020

\section{Информация об авторах}

Цзюнь Ма - аспирант Уральского федерального университета имени первого президента России Б.Н. Ельцина, Екатеринбург, Россия (620002, Екатеринбург, улица Мира, 19); e-mail: ma_dreama@hotmail.com

Майбуров Игорь Анатольевич - доктор экономических наук, профессор, заведующий кафедрой финансового и налогового менеджмента, Уральский федеральный университет им. первого Президента России Б. Н. Ельцина, г. Екатеринбург, Россия (620002, г. Екатеринбург, ул. Мира, 19); e-mail: mayburov.home@gmail.com.

ИНФОРМАЦИЯ О СТАТЬЕ: дата поступления 27 августа 2020 г.; дата принятия к печати 26 ноября 2020 г. 